\title{
Factors controlling the temporal dynamics of egg production in the copepod Temora longicornis
}

\author{
Claudia Castellani ${ }^{1,3, *}$, Yener Altunbaş ${ }^{2}$ \\ ${ }^{1}$ School of Ocean Sciences, University of Wales Bangor, Askew Street, Menai Bridge, LL57 5EY Anglesey, UK \\ ${ }^{2}$ School for Business and Regional Development (SBARD), University of Wales Bangor, LL57 2DG Gwynedd, UK \\ ${ }^{3}$ Present address: British Oceanographic Data Centre, Proudman building, 6 Brownlow Street, Liverpool L3 5DA, UK
}

\begin{abstract}
The factors controlling the temporal dynamics of egg production rate (EPR) in Temora longicornis were investigated during a 3 yr study. T. longicornis produced eggs all year round, with an annual maximum (EPR $\max$ ) between 27 and 48 eggs female ${ }^{-1} \mathrm{~d}^{-1}$ during spring/summer and minimum of 1.4 eggs female $\mathrm{e}^{-1} \mathrm{~d}^{-1}$ in autumn/winter. The highest EPR values were measured when copepods were heaviest and in situ chlorophyll a (chl) increased above $\sim 1$ to $3.5 \mu \mathrm{g} \mathrm{l^{-1 }}$, irrespective of ambient temperature. EPR was positively related to copepod body weight (BW) and chl, whereas it was negatively related to suspended particulate matter (SPM) and temperature. Stepwise multivariate analysis showed that copepod BW, chl and SPM explained most of the variability associated with fecundity, outweighing the effect of temperature. Moreover, the lower $\mathrm{EPR}_{\max }$ measured in spring 1996, as compared to 1997 and 1998, suggests that food nutritional quality was probably another important factor affecting copepod fecundity. Since BW was inversely related to temperature, by controlling copepod BW, temperature indirectly determined the maximum potential reproductive output of T. longicornis. Acting on at least in situ physical parameters like temperature and SPM, climate change could represent an important modulator of secondary production in this and other copepod species.
\end{abstract}

KEY WORDS: Fecundity $\cdot$ Temora longicornis $\cdot$ Body weight $\cdot$ Suspended sediment $\cdot$ Chlorophyll $a$. Temperature $\cdot$ Microplankton $\cdot$ Food limitation

\section{INTRODUCTION}

Egg production rate (EPR) is one of the most studied vital rates in copepods, and yet there is still incomplete understanding about the importance of the different physiological and environmental variables controlling the reproductive output of these organisms in situ. Previous studies have indicated that food ration (Kiørboe \& Nielsen 1994), food quality (Kleppel \& Hazzard 2000, Jónasdóttir et al. 2002), cell size (Dam \& Peterson 1991), temperature (White \& Roman 1992) and suspended sediments (Burdloff et al. 2000) are all important variables affecting copepod fecundity.

Body weight (BW) represents an intrinsic variable known to affect the rates of physiological processes (e.g. feeding, metabolism, growth) of invertebrates including reproduction (Schmidt-Nielsen 1991). So far, however, research has mostly focused on the effect of temperature (Hirakawa 1991, White \& Roman 1992) and food quantity and quality (Jónasdóttir 1994, Kiørboe \& Nielsen 1994), whereas the dependence of fecundity on copepod size has received limited attention (Kiørboe \& Sabatini 1995, Hopcroft \& Roff 1998, Bunker \& Hirst 2004). The relationship between copepod BW and EPR has been investigated for multispecies data (Kiørboe \& Sabatini 1995, Hopcroft \& Roff 1998, Bunker \& Hirst 2004), but investigations at the level of a single species and in relation to a range of environmental variables are lacking. Multi-species studies have reported scaling of fecundity with BW for some data sets (Bunker \& Hirst 2004), but not for others (Kiørboe \& Sabatini 1995). On the other hand, single- 
species studies have found contrasting results for the factors affecting fecundity in general even for the same species (Halsband \& Hirche 2001, Maps et al. 2005). Using multi-species or limited data sets may obscure subtle and important relationships between variables (Bunker \& Hirst 2004), particularly when simple statistical analysis is employed to resolve the complexity of data characterised by high variability, like fecundity. In this respect, multivariate statistical analysis can be a very powerful tool to establish relationships between variables (Dam \& Peterson 1991, Hopcroft \& Roff 1998).

Using a $3 \mathrm{yr}$ time series the present study investigated the factors controlling the in situ fecundity of Temora longicornis, one of the most abundant copepod species in many coastal areas of the northern hemisphere (Fransz et al. 1992, Peterson \& Kimmerer 1994, Williams et al. 1994). The EPR of T. longicornis in the field has been studied in the past, but there is still disagreement regarding which factors control the fecundity of this species (Halsband \& Hirche 2001, Maps et al. 2005). In particular, we addressed the following questions: (1) is in situ EPR related to copepod BW and (2) how important is BW for fecundity compared to other environmental factors like food availability, temperature and suspended sediments?

\section{MATERIALS AND METHODS}

Sampling. Plankton was collected weekly, between March 1996 and November 1998, using a 200 m mesh WP-2 plankton net fitted with a non-filtering cod-end from the St. George Pier, Menai Strait $\left(53^{\circ} 13^{\prime} \mathrm{N}\right.$, $4^{\circ} 09^{\prime} \mathrm{W}$ ) in the eastern Irish Sea. The sample was immediately transferred to an opalescent, polypropylene aspirator containing $10 \mathrm{l}$ of natural seawater; it was pre-screened through $250 \mu \mathrm{m}$ to exclude predators, and copepods were sorted within $1 \mathrm{~h}$ of collection.

Temperature $\left(T,{ }^{\circ} \mathrm{C}\right)$ and salinity $(S, \mathrm{ppt})$ were measured with a CTD (Braystoke, Series 600) throughout the water column during each sampling. Chlorophyll a (chl, $\mu \mathrm{g} \mathrm{l}^{-1}$ ) and microplankton samples were collected with a 21 Niskin bottle from $\sim 2 \mathrm{~m}$ depth. Chl concentration was determined from water samples of 100 to $750 \mathrm{ml}$, filtered onto GF/F filters, extracted in neutralised $90 \%$ acetone solution for $24 \mathrm{~h}$ at $4^{\circ} \mathrm{C}$ in the dark and measured using a Turner 10 fluorometer in accordance with the recommendations of Tett (1987). Microplankton was immediately fixed with Lugol's iodine to $2 \%$ final concentration (Kiørboe \& Nielsen 1994), stored into $100 \mathrm{ml}$ dark glass bottles in the dark at $4^{\circ} \mathrm{C}$ and analysed by the Utermöhl (1958) technique within 1 mo. Cellular dimensions of a minimum of 30 cells for each type were determined with an ocular micrometer $(\times 400)$ and used to calculate cell volume by assigning taxa to simple geometrical shapes. Cell volumes were converted to cell carbon with the equations of Strathmann (1967) for phytoplankton, Putt \& Stoecker (1989) for oligotrichous ciliates and Bartram (1980) for other heterotrophic protists. Data for total suspended particulate matter (SPM) were estimated from settled microplankton samples by looking at the percentage of the slide area covered by the detritus and assigning scores from 1 to 6 , corresponding to $\sim 0$ to $50 \mathrm{mg} \mathrm{l}^{-1}$ (Buchan et al. 1967 and SPM data for 1996, from Kratzer et al. 2000).

Egg production rates. Between 25 and 30 intact active female Temora longicornis were randomly selected from the catch, using a large bore plastic pipette. Individuals were placed into $250 \mathrm{ml}$ crystallising dishes filled with natural, $53 \mu \mathrm{m}$ pre-screened seawater. Measurements from single females were used to estimate individual variability in EPR and the proportion of reproductively active females (RAF) in the population. The dishes were kept for $24 \mathrm{~h}$ in a temperature-controlled water bath at the ambient surface temperature $\pm 0.2^{\circ} \mathrm{C}$ (i.e. $1 \mathrm{~m}$ depth), under artificial lighting, with an ambient light/dark regime. After incubation, the females were gently removed from the crystallising dishes with the pipette, the content of each dish was filtered through a $53 \mu \mathrm{m}$ sieve, and the eggs and nauplii were retained, stained with Lugol's iodine and counted in a Bogorov tray under a dissecting microscope. Copepods found dead or moribund at the end of the incubation time were not included in the analysis. EPR was converted to carbon production rates $\left(\mathrm{EPR}_{\mathrm{c}}\right)$ on the basis of monthly measurements of the diameter of 30 eggs with a high power microscope and conversion of egg volume to carbon, assuming $0.14 \times 10^{-6} \mu \mathrm{g} \mathrm{C} \mathrm{mm}^{-3}$ (Kiørboe et al. 1985). Egg hatching success was also measured, and results have already been reported elsewhere (Castellani \& Lucas 2003). The proportion of RAF for each sampling date was calculated as the ratio between the number of females producing eggs and the total number of females incubated.

The prosome length $(\mathrm{PL}, \mu \mathrm{m})$ of the females incubated was sized with an eye-piece graticule under a dissecting microscope, and length was converted to dry weight $(\mathrm{DW}, \mu \mathrm{g})$ with the relationship $\ln \mathrm{DW}=2.75$ $\times \ln$ PL $-15.9\left(\mathrm{r}^{2}=0.85, \mathrm{p}<0.001, \mathrm{df}=29\right)$ (Castellani 2002). Copepod DW was then converted to carbon by assuming a weight-specific carbon content of $40 \%$ (Omori \& Ikeda 1984).

Data analysis. Both simple and forward stepwise multiple regression were used to examine the relationship between the dependent variable $\mathrm{EPR}_{\mathrm{c}}(\mu \mathrm{g} \mathrm{C}$ female ${ }^{-1} \mathrm{~d}^{-1}$ ) and the independent variables BW $\left(\mu \mathrm{g}\right.$ C), chl concentration $\left(\mu \mathrm{g} \mathrm{l}^{-1}\right), T$ and total SPM (ordinal scale of $1=$ minimum to $6=$ maximum). $\mathrm{Chl}$ was chosen as the only proxy for food availability, as 
the measurements made on specific microplankton groups were limited.

The analysis was carried out using both individual measurements and means of EPR according to sampling date, including the zero values to compare these 2 different analytical approaches. Using individual measurements allows one to take into account more accurately the effect of body weight, particularly when its variation within a sampling event is large. However, this type of data may contain a large number of zero values (i.e. copepods which did not produce eggs) arising as a result of a methodological artefact, i.e. the females needing a longer incubation time than the standard $24 \mathrm{~h}$ to produce eggs. Under these circumstances the statistical analysis of individual values may overestimate the natural variability of the data and lower the slope estimated by the regression analysis between the variables. Mean estimates, on the other hand, although they may represent a more appropriate descriptor of the fecundity of the population, will artificially reduce the variability of the data and increase the explanatory power of the regression analysis. Thus, both analytical approaches were used for comparative purposes.

To examine the effect of the different variables in more detail, the data were analysed for smaller intervals of BW ( $\mu \mathrm{g} \mathrm{C},>3$ to $\leq 8 ;>8$ to $\leq 12 ;>12$ to $\leq 16 ;>16$ to $\leq 20 ;>20$ to 28 ), SPM concentrations (1 to 6 ) and temperature ranges $\left(\mathrm{T}, \leq 10^{\circ} \mathrm{C},>10^{\circ} \mathrm{C}\right)$. If an independent variable did not contribute significantly to the prediction, it was excluded, and the regression was completed using the remaining variables.

\section{RESULTS}

\section{Hydrography and environmental conditions}

The sampling station is characterised by shallow water depths mostly between 1 and $5 \mathrm{~m}$ (maximum $20 \mathrm{~m}$ ), strong tidal currents and high tidal ranges (3.4 to $6.6 \mathrm{~m}$ ), and therefore it is thoroughly mixed throughout the year. The water temperature recorded between 1996 and 1998 in the Menai Strait varied from a minimum of $2^{\circ} \mathrm{C}$ in winter to a maximum of $18^{\circ} \mathrm{C}$ in summer (Fig. 1a). The greatest inter-annual variation occurred between January and April, with the temperature in 1996 being $\sim 3.5$ and $\sim 4.5^{\circ} \mathrm{C}$ lower than in 1997 and 1998, respectively. Salinity changed little, reaching maximum values of 34.1 ppt in summer and a minimum of 31.7 ppt in autumn, during the highest local annual rainfall (i.e. 110 to $126 \mathrm{~mm} \mathrm{mo}^{-1}$, Royal Meteorological Society, Weather Log 1996 to 1998).

SPM concentration varied with wind strength, tidal range and season, with maximum values of $\sim 5$ to $50 \mathrm{mg}$
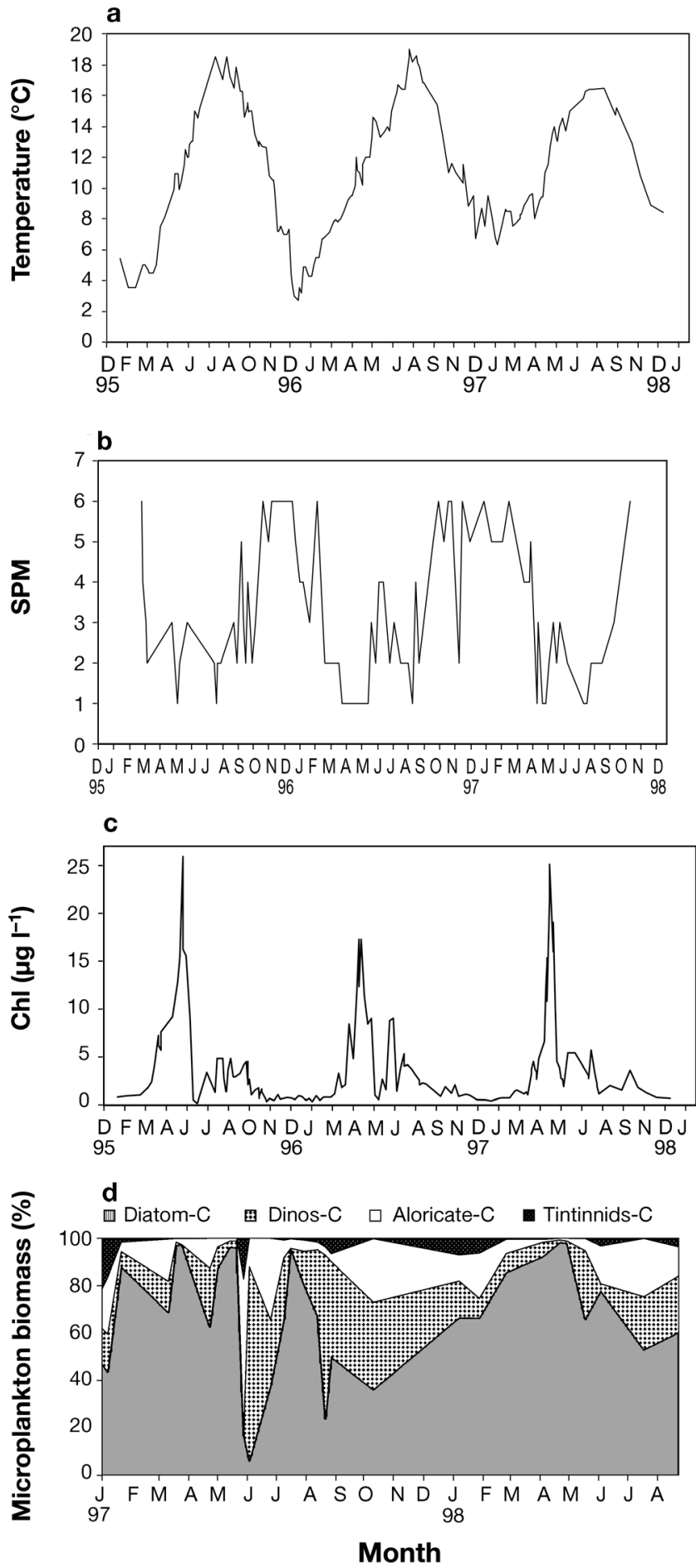

Fig. 1. Seasonal changes in (a) temperature, (b) suspended particulate matter (SPM, ordinal scale), (c) chlorophyll a (chl) and (d) microplankton biomass composition in the Menai Strait

$\mathrm{l}^{-1}$ in autumn/winter, minima of $\sim 0.5$ to $3 \mathrm{mg} \mathrm{l}^{-1}$ in late spring/early summer and intermediate concentrations of $\sim 3$ to $5 \mathrm{mg} \mathrm{l}^{-1}$ in late summer (Fig. 1b, Kratzer et al. 2000). 


\section{Chlorophyll $a$ and microplankton}

The seasonal changes in the in situ chl concentration and the biomass composition of the main microplankton groups are shown in Fig. 1c,d. The early spring increase of chl from the low winter concentration of $0.5-0.9$ to $\sim 3-8 \mu \mathrm{g} \mathrm{l}^{-1}$ was almost exclusively diatomaceous and included species like Ditylum brightwelli, Skeletonema costatum, Chaetoceros sp., Asterionella sp. and Thalassiosira sp.. Between April and June the microplankton community was replaced by the mixed diatom-flagellate bloom of Phaeocystis sp.-Rhizosolenia delicatula, and chl increased to $\sim 16-26 \mu \mathrm{g} \mathrm{l}^{-1}$. The spring bloom was followed by an increase in euglenoids and cryptomonas-like flagellates. A series of monospecific diatom blooms of Leptocylindrus danicus, Rhizosolenia styliformis and Guinardia flaccida developed in summer and autumn, with chl ranging between $\sim 3$ and $8 \mu \mathrm{g} \mathrm{l}^{-1}$. Ciliate biomass, mostly belonging to the genus Strombidium, also peaked between spring and early summer and was correlated to chl concentration $(r=0.67, p<0.05, d f=33)$. Dinoflagellates, on the other hand, peaked in the summer, after the chl maxima.

\section{Seasonal and inter-annual variation in fecundity}

Temora longicornis produced eggs all year round, with mean $( \pm$ SE) EPR ranging from $\sim 1.3 \pm 0.5$ eggs female $^{-1} \mathrm{~d}^{-1}$ in autumn/winter to $\sim 48 \pm 7$ eggs female $\mathrm{e}^{-1} \mathrm{~d}^{-1}$ in spring/summer (Fig. 2). EPR also differed from year to year. In 1996 a fecundity maximum of $\sim 23 \pm 3$ eggs female ${ }^{-1} \mathrm{~d}^{-1}$ occurred in June, and was approximately half of that measured in May of $1997\left(44 \pm 6\right.$ eggs female $\left.{ }^{-1} \mathrm{~d}^{-1}\right)$ and $1998(48 \pm 7$ eggs female $\left.{ }^{-1} \mathrm{~d}^{-1}\right)$. Mean $( \pm \mathrm{SE})$ copepod BW also varied seasonally, with the lightest $(4.5 \pm 0.9 \mu \mathrm{g} \mathrm{C})$ copepods in summer/autumn and the heaviest (18.7 $\pm 2.5 \mu \mathrm{g} \mathrm{C}$ ) in winter/spring (Fig. 2). Thus, BW was inversely correlated with in situ temperature (Fig. 2, Table 1). Over the year individual females produced from 0 to 116 eggs female $\mathrm{e}^{-1} \mathrm{~d}^{-1}$, and the proportion of reproductively active females also varied seasonally, from up to $100 \%$ in spring/summer to just $21 \%$ in autumn/ winter (Fig. 3).

The general decrease in RAF to $<50 \%$ in winter and at the end of summer indicates that, at this time, the environmental and/or the physiological conditions of the copepods were not optimal to induce maximal reproduction in the population.

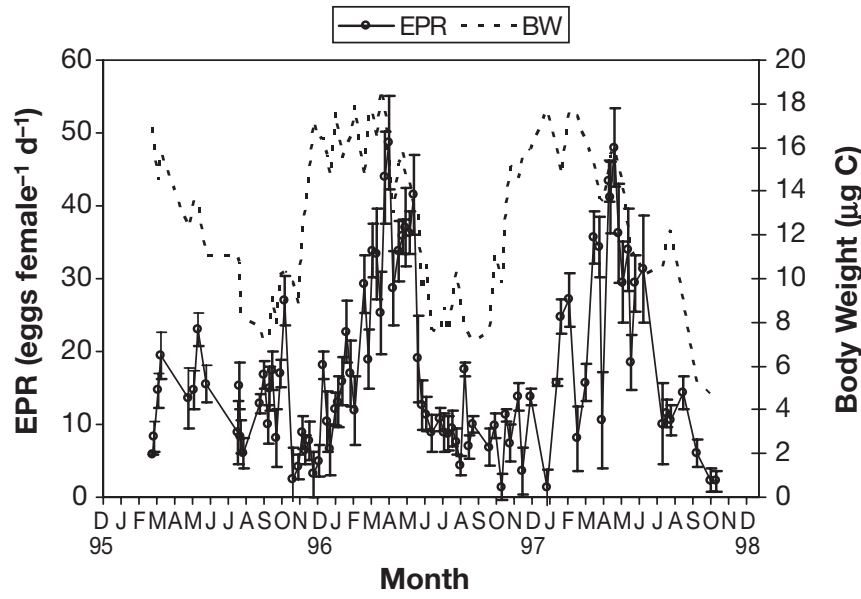

Fig. 2. Temora longicornis. Seasonal change in mean $( \pm \mathrm{SE})$ egg production rate (EPR) and copepod body weight (BW)

\section{EPR versus BW, chl, SPM and T}

Tables 1 \& 2 summarise the relationships found for fecundity versus BW, chl, SPM and Tand BW versus $T$. The scatterplot in Fig. 4 shows that EPR increases with BW according to a linear relationship. The apparent decline in EPR for copepod body weight $>22 \mu \mathrm{g}$ C may be an artefact due to the limited number of observations available for the largest copepods.

Fecundity also increased with chl, and both a linear and an asymptotic relationship could describe the relationship equally well. A series of Ivlev's curves was fitted to the mean EPR for different BW groups. The curves show that both maximum fecundity $\left(\mathrm{EPR}_{\max }\right)$ and the concentration of chl required to reach $\mathrm{EPR}_{\max }$ increase for all the BW groups, suggesting that food availability represents a limiting factor for fecundity across the size range (Fig. 5, Table 3).

The relationship between EPR and $T$ is more complex, and appears to be described by a dome shape, with $\mathrm{EPR}_{\max }$ occurring between 9 and $14^{\circ} \mathrm{C}$ (Fig. 6).

Table 1. Temora longicornis. Regression analysis of $\mathrm{EPR}_{c}$ (egg production rate, $\mu \mathrm{g} \mathrm{C}$ female ${ }^{-1} \mathrm{~d}^{-1}$ ) versus suspended particulate matter (SPM, ordinal scale), body weight (BW, $\mu \mathrm{g} \mathrm{C})$, chlorophyll $a\left(\mathrm{chl}, \mu \mathrm{g} \mathrm{l^{-1 }}\right)$ and temperature $\left(T,{ }^{\circ} \mathrm{C}\right)$, and BW versus $T$. Significance level: ${ }^{* * *} 1 \% ; \mathrm{n}$ : number of observations; standard error given in parentheses

\begin{tabular}{|c|c|c|c|c|c|}
\hline Variables & $\mathrm{n}$ & Intercept & Slope & $r^{2}$ & $F$ \\
\hline $\mathrm{EPR}_{\mathrm{c}}$ vs. SPM & 2228 & $1.119^{* * *}(0.034)$ & $-0.142^{* * *}(0.009)$ & 9.4 & 230.30 \\
\hline $\mathrm{EPR}_{\mathrm{c}}$ vs. BW & 2228 & $0.040 \quad(0.046)$ & $0.049^{* * *}(0.005)$ & 8.3 & 201.72 \\
\hline $\mathrm{EPR}_{\mathrm{c}}$ vs. chl & 2228 & $0.451^{* * *}(0.021)$ & $0.057^{* * *}(0.004)$ & 8.5 & 207.03 \\
\hline EPR $_{\mathrm{c}}$ vs. $T$ & 2228 & $0.879^{* * *}(0.048)$ & $-0.020^{* * *}(0.004)$ & 1.1 & 25.37 \\
\hline BW vs. $T$ & 2228 & $20.2 \quad(0.219)$ & $0.673 \quad(0.018)$ & 38.7 & 1410.6 \\
\hline
\end{tabular}




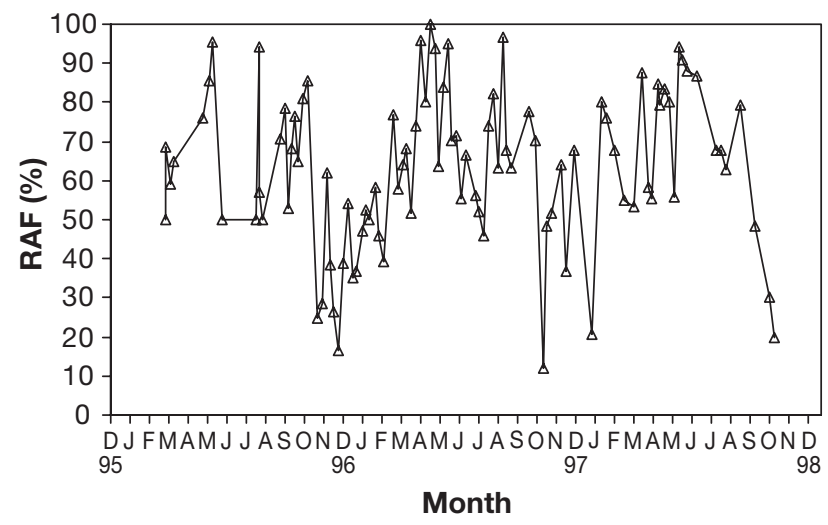

Fig. 3. Temora longicornis. Seasonal variation in the proportion of reproductively active females (RAF)

Fecundity was also inversely related to SPM over the year (Table 1$)$ and to mean tidal range $(\mathrm{r}=-0.99, \mathrm{p}<$ $0.001, \mathrm{df}=4$, Fig. 7). This result suggests that an increase in suspended sediment may affect EPR by interfering with the feeding behaviour (i.e. food handling and/or ingestion efficiency) and/or decreasing the quality of the food ingested by the copepod.

\section{Stepwise multiple regression}

The results of the stepwise multiple regression analysis between copepod fecundity, BW, chl, $T$ and SPM are shown in Table 4 . The best fit was found for nontransformed data.

Tables $2 \& 4$ show that there were no significant differences between the slopes of the single and multiple regressions estimated from either means or individual measurements of fecundity. It is also noteworthy that, using individual estimates, the effect of temperature could be clearly identified, whereas this variable was not significant using the mean fecundity values (Table 4). The multiple regression analysis of individual measurements shows that fecundity was positively related to BW and chl, whereas it was negatively related to SPM concentration and $T$. The most important variables explaining the variability in fecundity

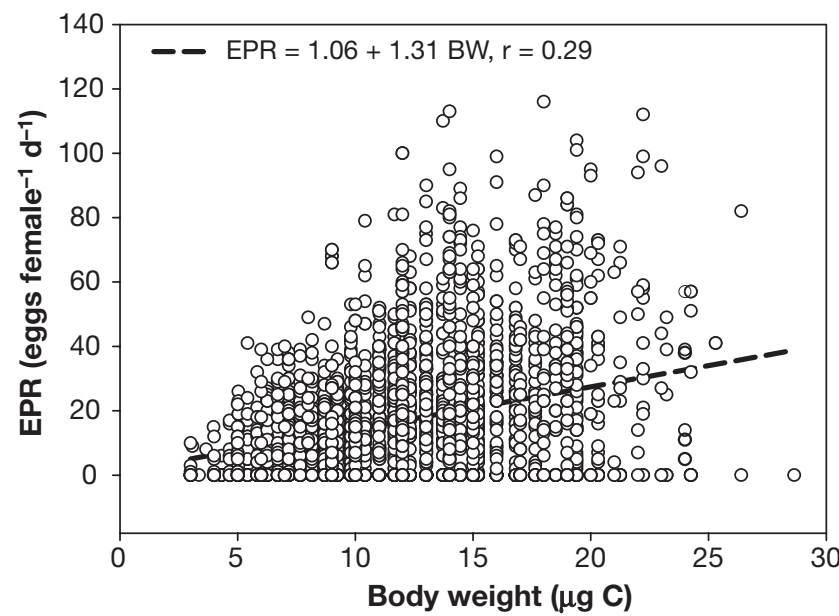

Fig. 4. Temora longicornis. Scatterplot of egg production rate (EPR) and copepod body weight (BW)

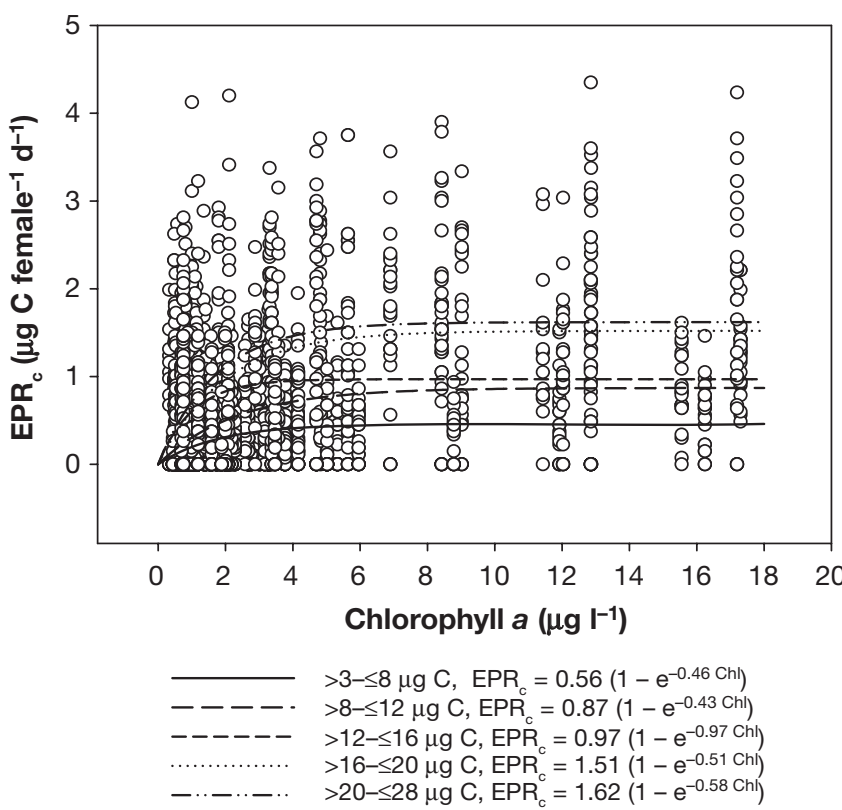

Fig. 5. Temora longicornis. Scatterplot of egg production rate (EPR) expressed as carbon $\mathrm{EPR}_{\mathrm{C}}$ versus chlorophyll $a$. Ivlev's curves, $\mathrm{EPR}=\mathrm{EPR}_{\max } \times\left(1-\mathrm{e}^{\mathrm{k} \times \mathrm{chl}}\right)$, fitted to mean EPRs for different copepod size groups (BW, $\mu \mathrm{g}$ C); $k$ is the rate at which EPR approaches its asymptote $\left(\mathrm{EPR}_{\max }\right)$

Table 2. Temora longicornis. Comparison of regression slopes for EPR (eggs female ${ }^{-1} \mathrm{~d}^{-1}$ ) versus BW, in terms of (1) individual EPR, (2) mean EPR according to sampling date (irrespective of BW) and (3) mean EPR of different BW groups (irrespective of sampling date). Further details as in Table 1

\begin{tabular}{|c|c|c|c|c|c|c|}
\hline $\begin{array}{l}\text { Regression type } \\
\text { (EPR vs. BW) }\end{array}$ & $\mathrm{n}$ & Intercept & Slope & $\mathrm{r}^{2}$ & $\begin{array}{c}\text { Comparison } \\
\text { of slopes }\end{array}$ & $t$-statistic \\
\hline (1) Individual EPR values & 2228 & $1.06(1.22)$ & $1.32^{* * *}(0.093)$ & 8.3 & - & - \\
\hline (2) Mean EPRs (sampling date) & 95 & $-0.37(3.97)$ & $1.42^{* * *}(0.31)$ & 18.5 & $1-2$ & 0.17 \\
\hline (3) Mean EPRs (BW group) & 24 & $-0.71(2.36)$ & $1.41^{* * *}(0.15)$ & 80.8 & $1-3$ & 0.16 \\
\hline
\end{tabular}


Table 3. Temora longicornis. Relationship between $\mathrm{EPR}_{\mathrm{c}}(\mu \mathrm{g}$ $\mathrm{C}$ female $\left.\mathrm{e}^{-1} \mathrm{~d}^{-1}\right)$ and chl $\left(\mu \mathrm{g} \mathrm{l} \mathrm{l}^{-1}\right)$. Ivlev's curves $\mathrm{EPR}_{\mathrm{c}}=\mathrm{EPR}_{\max } \times$ $\left(1-\mathrm{e}^{-k \times \mathrm{chl}}\right)$, fitted to the mean EPR for different copepod size groups (BW, $\mu \mathrm{g}$ C). Max: maximum; $k$ : the rate at which EPR approaches its asymtote $\left(\mathrm{EPR}_{\max }\right)$; further details as in Table 1

\begin{tabular}{|lcccc|}
\hline BW & $\mathrm{n}$ & $k$ & $\mathrm{EPR}_{\max }$ & $\mathrm{r}^{2}$ \\
\hline$>3$ to $\leq 8$ & 39 & $0.46(0.331)$ & $0.56(0.191)$ & 12.4 \\
$>8$ to $\leq 12$ & 90 & $0.43(0.127)$ & $0.86(0.105)$ & 10.5 \\
$>12$ to $\leq 16$ & 83 & $0.97(0.294)$ & $0.96(0.975)$ & 13.3 \\
$>16$ to $\leq 20$ & 55 & $0.51(0.134)$ & $1.51(0.155)$ & 32.9 \\
$>20$ to $\leq 28$ & 38 & $0.58(0.212)$ & $1.62(0.196)$ & 30.7 \\
\hline
\end{tabular}

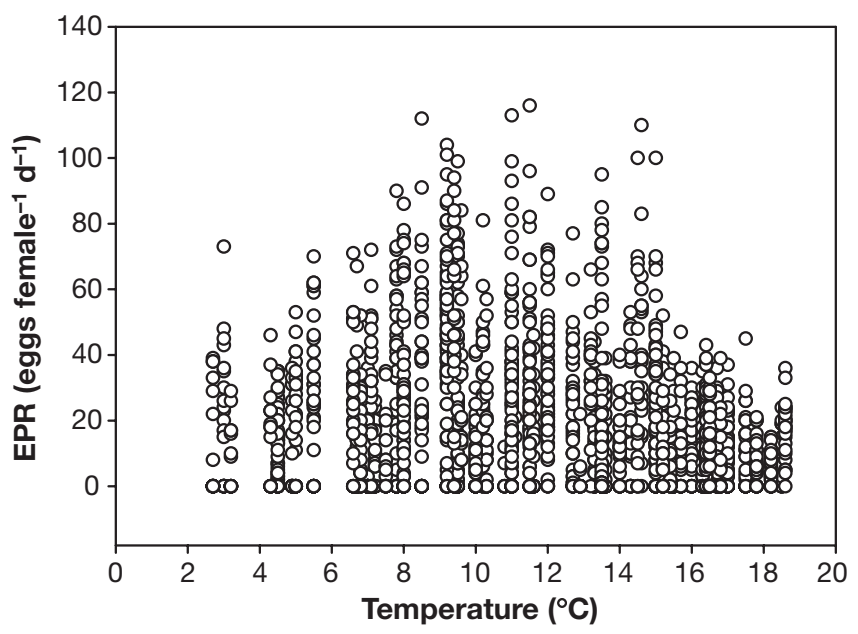

Fig. 6. Temora longicornis. Scatterplot of egg production rate (EPR) versus field temperature

were SPM, BW and chl, whereas $T$, although significant, made the least contribution (Tables 1 \& 3).

The results of the multiple regressions carried out on the SPM data subsets show that BW was consistently

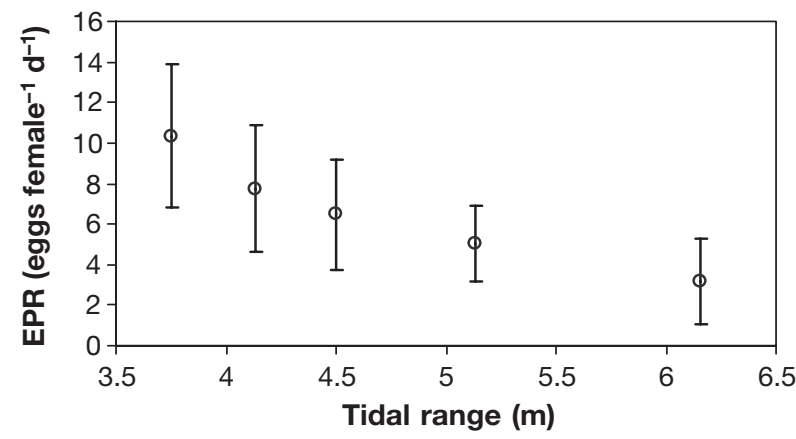

Fig. 7. Temora longicornis. Mean $( \pm \mathrm{SE})$ egg production rate (EPR) versus tidal range egg production rate (EPR), measured between November 1996 and January 1997

significant for different SPM concentrations, whereas chl and $T$ have no or less consistent explanatory power. Moreover, there is a tendency for the strength of the relationship between EPR and the other variables to decrease with increasing SPM (Table 5). Similarly, the effect of SPM was consistently negative and significant across the different BW groups, whereas the relationship between fecundity, chl and $T$ was not (Table 6). Considering the 2 temperature intervals above and below $10^{\circ} \mathrm{C}$, the relationship between EPR, BW, chl and SPM was consistent with the results reported above, and the explanatory power of these variables appears stronger within each data subset (Table 7).

\section{DISCUSSION}

The present study has investigated the factors controlling the fecundity of Temora longicornis over a $3 \mathrm{yr}$ survey. The data set was compiled by measuring individually the EPRs of 2228 females of body weights between 3 and $29 \mu \mathrm{g} \mathrm{C}$, over a wide range of in situ

Table 4. Temora longicornis. Stepwise multiple regression analysis $\left(\mathrm{EPR}_{\mathrm{c}}=a+b_{1} \mathrm{SPM}+b_{2} \mathrm{BW}+b_{3} \mathrm{chl}+b_{4} T\right)$ between either individual $\mathrm{EPR}_{\mathrm{c}}\left(1\right.$ to 4 , in $\mu \mathrm{g} \mathrm{C}$ female ${ }^{-1} \mathrm{~d}^{-1}$ ) or mean $\mathrm{EPR}_{\mathrm{c}}$ for each sampling date (5) and SPM (ordinal scale), BW ( $\mu \mathrm{g} \mathrm{C}$ ), chl $\left(\mu \mathrm{g} \mathrm{l}^{-1}\right)$ and $T\left({ }^{\circ} \mathrm{C}\right)$. Significance levels: ${ }^{*} 10 \% ;{ }^{* * *} 1 \%$. Further details as in Table 1

\begin{tabular}{|c|c|c|c|c|c|c|c|c|}
\hline Estimated model & $\mathrm{n}$ & $\begin{array}{l}\text { Intercept } \\
\quad(a)\end{array}$ & $\begin{array}{c}\text { SPM } \\
\left(b_{1}\right)\end{array}$ & $\begin{array}{l}\mathrm{BW} \\
\left(b_{2}\right)\end{array}$ & $\begin{array}{l}\text { Chl } \\
\left(b_{3}\right)\end{array}$ & $\begin{array}{c}T \\
\left(b_{4}\right)\end{array}$ & $\mathrm{r}^{2}$ & $F$ \\
\hline (1) $\mathrm{EPR}_{\mathrm{C}}=a+b_{1} \mathrm{SPM}$ & 2228 & $\begin{array}{l}1.119^{* * *} \\
(0.035)\end{array}$ & $\begin{array}{l}-0.142^{* * *} \\
(0.009)\end{array}$ & & & & 9.4 & 230.30 \\
\hline $\begin{array}{l}\text { (2) } \mathrm{EPR}_{\mathrm{c}}=a+b_{1} \mathrm{SPM}+ \\
b_{2} \mathrm{BW}\end{array}$ & 2228 & $\begin{array}{l}0.482^{* * *} \\
(0.049)\end{array}$ & $\begin{array}{l}-0.158^{* * *} \\
(0.009)\end{array}$ & $\begin{array}{l}0.055^{* * *} \\
(0.003)\end{array}$ & & & 19.7 & 273.36 \\
\hline $\begin{array}{l}\text { (3) } \mathrm{EPR}_{\mathrm{c}}=a+b_{1} \mathrm{SPM}+ \\
b_{2} \mathrm{BW}+b_{3} \mathrm{chl}\end{array}$ & 2228 & $\begin{array}{l}0.316^{* * *} \\
(0.055)\end{array}$ & $\begin{array}{l}-0.126^{* * *} \\
(0.010)\end{array}$ & $\begin{array}{l}0.052^{* * *} \\
(0.003)\end{array}$ & $\begin{array}{l}0.028^{* * *} \\
(0.004)\end{array}$ & & 21.3 & 200.6 \\
\hline $\begin{array}{l}\text { (4) } \mathrm{EPR}_{\mathrm{c}}=a+b_{1} \mathrm{SPM}+ \\
b_{2} \mathrm{BW}+b_{3} \mathrm{chl}+b_{4} T\end{array}$ & 2228 & $\begin{array}{l}0.816^{* * *} \\
(0.125)\end{array}$ & $\begin{array}{l}-0.150^{* * *} \\
(0.011)\end{array}$ & $\begin{array}{l}0.040^{* * *} \\
(0.004)\end{array}$ & $\begin{array}{l}0.027^{* * *} \\
(0.004)\end{array}$ & $\begin{array}{l}-0.023^{* * *} \\
(0.005)\end{array}$ & 22.0 & 156.72 \\
\hline $\begin{array}{l}\text { (5) } \mathrm{EPR}_{\mathrm{c}}(\text { mean) }=a+ \\
b_{1} \mathrm{SPM}+b_{2} \mathrm{BW} \text { (mean) }+ \\
b_{3} \mathrm{chl}+b_{4} T\end{array}$ & 95 & $\begin{array}{c}0.625^{*} \\
(0.349)\end{array}$ & $\begin{array}{c}-0.15^{* * *} \\
(0.023)\end{array}$ & $\begin{array}{l}0.046^{* * *} \\
(0.013)\end{array}$ & $\begin{array}{l}0.023^{* * *} \\
(0.008)\end{array}$ & $\begin{array}{c}-0.013 \\
(0.0132)\end{array}$ & 61.5 & 35.88 \\
\hline
\end{tabular}


Table 5. Temora longicornis. Stepwise multiple regression analysis $\left(\mathrm{EPR}_{\mathrm{c}}=a+b_{1} \mathrm{BW}+b_{2} \operatorname{chl}+b_{3} T\right)$ between $\mathrm{EPR}_{\mathrm{c}}(\mu \mathrm{Cg}$ female $\left.{ }^{-1} \mathrm{~d}^{-1}\right)$, BW $(\mu \mathrm{g} \mathrm{C})$, chl $\left(\mu \mathrm{g}^{-1}\right)$ and $T\left({ }^{\circ} \mathrm{C}\right)$ for different SPM concentrations (ordinal scale). Significance levels: ${ }^{*} 10 \%$; ${ }^{* *} 5 \%$; ${ }^{* * *} 1 \%$. Further details as in Table 1

\begin{tabular}{|c|c|c|c|c|c|c|c|c|c|c|c|}
\hline \multirow{2}{*}{$\frac{\text { SPM }}{1}$} & \multirow{2}{*}{$\begin{array}{c}\mathrm{n} \\
303\end{array}$} & \multicolumn{2}{|c|}{ Intercept (a) } & \multicolumn{2}{|c|}{$\mathrm{BW}\left(b_{1}\right)$} & \multicolumn{2}{|c|}{$\operatorname{Chl}\left(b_{2}\right)$} & \multicolumn{2}{|l|}{$T\left(b_{3}\right)$} & \multirow{2}{*}{$\frac{r^{2}}{15.9}$} & \multirow{2}{*}{$\begin{array}{c}F \\
18.84\end{array}$} \\
\hline & & $1.160^{* *}$ & $(0.49)$ & $0.072^{* * *}$ & $(0.02)$ & -0.017 & $(0.013)$ & $-0.061^{* *}$ & $(0.025)$ & & \\
\hline 2 & 633 & $0.739^{* * *}$ & $(0.22)$ & $0.031^{* * *}$ & $(0.008)$ & $0.034^{* * *}$ & $(0.006)$ & $-0.042^{* * *}$ & $(0.01)$ & 20.7 & 54.70 \\
\hline 3 & 414 & -0.2 & $(0.275)$ & $0.068^{* * *}$ & $(0.011)$ & $0.029^{* * *}$ & $(0.011)$ & 0.004 & $(0.013)$ & 18.2 & 30.43 \\
\hline 4 & 276 & 0.383 & $(0.28)$ & $0.023^{*}$ & $(0.013)$ & -0.015 & $(0.022)$ & -0.009 & (0.015) & 6 & 5.80 \\
\hline 5 & 220 & -0.406 & $(0.256)$ & $0.054^{* * *}$ & $(0.011)$ & -0.014 & $(0.028)$ & 0.021 & $(0.014)$ & 13 & 10.74 \\
\hline 6 & 382 & 0.042 & $(0.125)$ & $0.018^{* * *}$ & $(0.005)$ & $0.119^{* *}$ & $(0.048)$ & $-0.018^{* *}$ & $(0.009)$ & 5.3 & 7.08 \\
\hline
\end{tabular}

Table 6. Temora longicornis. Stepwise multiple regression analysis $\left(\mathrm{EPR}_{\mathrm{c}}=a+b_{1} \mathrm{SPM}+b_{2} \operatorname{chl}+b_{3} T\right)$ between $\mathrm{EPR}_{\mathrm{c}}(\mu \mathrm{g} \mathrm{C}$ female $\left.{ }^{-1} \mathrm{~d}^{-1}\right)$, SPM (ordinal scale), chl $\left(\mu \mathrm{g} \mathrm{l}^{-1}\right)$ and $T\left({ }^{\circ} \mathrm{C}\right)$ for different copepod BW $\left(\mu \mathrm{C}\right.$ C) ranges. Significance levels: ${ }^{* *} 5 \%$; ${ }^{* * *} 1 \%$. Further details as in Table 1

\begin{tabular}{|c|c|c|c|c|c|c|c|}
\hline BW & $\mathrm{n}$ & Intercept (a) & $\operatorname{SPM}\left(b_{1}\right)$ & Chl $\left(b_{2}\right)$ & $T\left(b_{3}\right)$ & $\mathrm{r}^{2}$ & $F$ \\
\hline$>3$ to $\leq 8$ & 400 & $-0.072(0.24)$ & $-0.057^{* * *}(0.016)$ & $0.024(0.011)$ & $0.009^{* *}(0.011)$ & 15.8 & 18.54 \\
\hline$>8$ to $\leq 12$ & 714 & $0.153(0.27)$ & $-0.117^{* * *}(0.019)$ & $0.013^{* *}(0.007)$ & $-0.023^{* * *}(0.008)$ & 15.2 & 31.84 \\
\hline$>12$ to $\leq 16$ & 585 & $1.224^{* *}(0.47)$ & $-0.200^{* * *}(0.023)$ & $0.009(0.008)$ & $-0.024^{* *}(0.010)$ & 17.2 & 30.09 \\
\hline$>16$ to $\leq 20$ & 418 & $0.982(0.64)$ & $-0.172^{* * *}(0.029)$ & $0.046^{* * *}(0.012)$ & $-0.009(0.017)$ & 22 & 29.07 \\
\hline$>20$ to $\leq 28$ & 111 & $1.841(1.44)$ & $-0.181^{* *}(0.077)$ & $0.011(0.027)$ & $0.067(0.055)$ & 17.4 & 5.6 \\
\hline
\end{tabular}

Table 7. Temora longicornis. Stepwise multiple regression analysis $\left(\mathrm{EPR}_{\mathrm{c}}=a+b_{1} \mathrm{SPM}+b_{2} \mathrm{BW}+b_{3} \mathrm{chl}+b_{4} T\right)$ between $\mathrm{EPR}_{\mathrm{c}}$ ( $\mu \mathrm{g} \mathrm{C}$ female ${ }^{-1} \mathrm{~d}^{-1}$ ) and SPM (ordinal scale), BW ( $\mu \mathrm{g} \mathrm{C}$ ), chl $\left(\mu \mathrm{g} \mathrm{l} \mathrm{l}^{-1}\right.$ ) and $T\left({ }^{\circ} \mathrm{C}\right)$ for the ranges $T \leq 10^{\circ} \mathrm{C}$ and $T>10^{\circ} \mathrm{C}$. Further details as in Table 1

\begin{tabular}{|rrrcccrrr|}
\hline$T\left({ }^{\circ} \mathrm{C}\right)$ & $\mathrm{n}$ & Intercept $(a)$ & $\operatorname{SPM}\left(b_{1}\right)$ & $\mathrm{BW}\left(b_{2}\right)$ & $\mathrm{Chl}\left(b_{3}\right)$ & $T\left(b_{4}\right)$ & $\mathrm{r}^{2}$ & $F$ \\
\hline$\leq 10$ & 848 & $0.719^{* * *}(0.19)$ & $-0.175^{* * *}(0.021)$ & $0.024^{* * *}(0.008)$ & $0.048^{* * *}(0.012)$ & $0.037^{* * *}(0.015)$ & 22.7 & 62.99 \\
$>10$ & 1315 & $1.073^{* * *}(0.20)$ & $-0.118^{* * *}(0.014)$ & $0.047^{* * *}(0.006)$ & $0.014^{* * *}(0.005)$ & $-0.048^{* * *}(0.010)$ & 25.6 & 112.69 \\
\hline
\end{tabular}

variables, like chlorophyll a $\left(0.3\right.$ to $\left.17.3 \mu \mathrm{g} \mathrm{l}^{-1}\right)$, temperature $\left(2.5\right.$ to $\left.18.5^{\circ} \mathrm{C}\right)$ and suspended sediments $(0.5$ to $50 \mathrm{mg} \mathrm{l}^{-1}$ ). As such, the present research is one of the most comprehensive studies ever conducted on the fecundity of this copepod species.

Our data show that Temora longicornis breeds continuously throughout the year, with EPRs following a seasonal pattern and magnitudes comparable to those reported for other temperate areas (Kiørboe \& Nielsen 1994, Peterson \& Kimmerer 1994, Peterson \& Dam 1996, Halsband \& Hirche 2001). The results of the stepwise multiple regression analysis, from the present study, suggest that BW, chl and SPM are key parameters controlling the EPR of T. longicornis, whereas the effect of $T$, although significant, is less important (Tables 1 \& 3).

\section{Effect of body weight on fecundity}

Temora longicornis reproduced at a maximum rate $\left(E P R_{\max }\right)$ during spring when copepods where heaviest and at a minimum rate $\left(\mathrm{EPR}_{\mathrm{min}}\right)$ in summer/autumn when copepods were lightest (Figs. 2 \& 4). As a result, fecundity was positively related to BW, which accounted for a large part of the variability explained by the multiple regression analysis (Tables $1 \& 3$ ). The positive, significant relationship found between EPR and BW, in the present study, contrasts with results from previous investigations (Halsband \& Hirche 2001, Maps et al. 2005). Maps et al. (2005) argued that food availability rather than BW was the main factor regulating the fecundity of $T$. longicornis in the Gulf of St. Lawrence, while Halsband \& Hirche (2001) could not find any significant correlation between EPR, PL and chl for this species in the North Sea. However, based on a significant correlation between clutch size and PL, Halsband \& Hirche (2001) speculated that body size rather than food sources regulated the fecundity of $T$. longicornis.

BW has already been reported as an important determinant of egg mass for several copepod species (Runge 1985, Bunker \& Hirst 2004). Nevertheless, not many investigations have explored the relationship between fecundity and body weight. In addition, the majority of the studies to date have limited their analysis to multiple rather than single species (Kiørboe \& 
Sabatini 1995, Hopcroft \& Roff 1998, Bunker \& Hirst 2004). The lack of correlation between variables reported is probably due to the fact that none of the previous studies on Temora longicornis has thoroughly investigated the combined effects of $\mathrm{BW}, \mathrm{chl}$ and $T$ at the high frequency (i.e. weekly) measurements and over the full range of variables reported by the present study. For instance, Maps et al. (2005) conducted their field study over a restricted part of the year, and, thus, the lack of relationship they reported between EPR and BW was probably due to the similarity in the size of the copepods they studied (see their Table 2). Similarly, the lack of scaling between EPR and BW reported for multiple copepod species by Kiørboe \& Sabatini (1995) has been attributed to the use of a limited data set (Bunker \& Hirst 2004). In addition, both Halsband \& Hirche (2001) and Maps et al. (2005) used simple correlation analysis on means rather than on individual observations. By using this approach, they reduced both the sample size and the variability in their data set and, therefore, probably limited the possibility of finding a significant correlation among the variables they studied. For instance, results from the present study indicate that, although the parameters estimated using either individual or mean values are the same, temperature was significantly correlated to fecundity only when using individual values. We will return to the differences in methodological approaches used by different studies (see section 'Methodological and statistical considerations in the analysis of EPR data').

\section{Fecundity versus temperature}

The relationship between fecundity and temperature, found in the present study, was negative and weaker than that between EPR and the other variables (Tables $1 \& 3$ ). Such a relationship largely arose from the observed decrease in Temora longicornis EPR at field temperatures $>10^{\circ} \mathrm{C}$ (Fig. 6, Table 7). A rise in temperature usually results in an increase in the physiological rates of poikilotherms up to an optimum beyond which conditions become sub-optimal or detrimental to life processes (Schmidt-Nielsen 1991). However, laboratory experiments have shown that, under food-saturated conditions, $T$. longicornis fecundity reaches a maximum around $18^{\circ} \mathrm{C}$ (Halsband-Lenk et al. 2002), i.e. greater than or equal to the maximum field temperature experienced by this species in our study area. Similarly, the low EPR measured in winter, when copepods reached their largest sizes, was probably not due to low temperature (i.e. $\sim 3$ to $8^{\circ} \mathrm{C}$ ). Laboratory studies have indeed shown that, under food-saturated conditions, $T$. longicornis fecundity is temperature limited at $2^{\circ} \mathrm{C}$ (Maps et al. 2005). However, the data pre- sented by Kiørboe \& Nielsen ([1994], see their Figs. 4B \& 5C) clearly show an $E P R_{\max }$ for $T$. longicornis at $\sim 5^{\circ} \mathrm{C}$ during the spring phytoplankton bloom, demonstrating that, provided an adequate food source is available, this species can reproduce maximally even at such low temperatures. The minimum field temperatures encountered by $T$. longicornis, in the present study, never dropped below $5^{\circ} \mathrm{C}$ throughout winter, with the exception of the $\sim 3^{\circ} \mathrm{C}$ measured in early January 1996 and 1997. Moreover, the high 'spring-like' temperatures of $\sim 8.5^{\circ} \mathrm{C}$ we recorded in the winter of 1998 did not promote any increase in T. longicornis EPR until the chl concentration in the field rose $>0.5 \mu \mathrm{g}$ chl $\mathrm{l}^{-1}$, suggesting that fecundity was food limited. Such a low EPR in winter might have also been exacerbated by the fact that copepods at this time of the year were heaviest and thus required more energy to meet metabolic costs (C. Castellani unpubl. data) and/or to initiate reproduction.

Other studies have reported positive scaling between the EPR of multiple species and temperature, although, consistently with our results, temperature did only have low explanatory power of copepod fecundity (Bunker \& Hirst 2004). The reason for the difference and reduced effect of temperatures on EPR, across studies, is probably to be attributed in part to both the effects of BW and food limitation on fecundity. In the present study, the negative scaling between fecundity and temperature was due to the fact that at the lower temperatures copepods were larger and EPR was on average greater than at the warmer temperatures (Fig. 6). When food resources in situ are limiting, temperature is unlikely to accurately predict changes in copepod fecundity with BW, as any ingested/stored energy would probably be channelled towards basic metabolism rather than reproduction.

\section{Fecundity versus chlorophyll a}

Findings of the current study regarding in situ food limitation of Temora longicornis fecundity support what has been reported for this species by some field studies (Peterson \& Bellantoni 1987, Bautista et al. 1994, Kiørboe \& Nielsen 1994, Peterson \& Kimmerer 1994, Maps et al. 2005), but not by others (Halsband \& Hirche 2001). Although, T. longicornis reproduced throughout the year, $\mathrm{EPR}_{\max }$ was only achieved at microplankton carbon values ranging from $\sim 12$ to $200 \mu \mathrm{g} \mathrm{Cl}^{-1}$ and at chl $>1$ to $3.5 \mu \mathrm{g} \mathrm{l}^{-1}$ (Fig. 5), a value

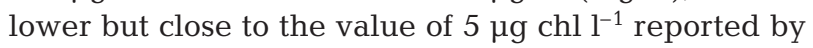
Peterson \& Bellantoni (1987) for this species in Long Island Sound. Further evidence of food limitation on fecundity, in the present study, is provided by the fact that the chl concentration at which $\mathrm{EPR}_{\max }$ occurred 
coincides with the $3.5 \mu \mathrm{g} \mathrm{l}^{-1}$ (for phytoplankton cells $>20 \mu \mathrm{m}$ ) at which the ingestion rate of $T$. longicornis is maximum (Dam \& Peterson 1991). In addition, Ivlev's relationships show a saturation of EPR with increasing chl concentration for all BW groups, indicating that food limitation was not restricted to the largest copepods, but occurred over the full BW range (Fig. 5, Table 3). In contrast, Halsband \& Hirche (2001) could not find any significant relationship between EPR and $\mathrm{chl}$, and concluded that the in situ fecundity of $T$. longicornis was not food limited. In their study, however, Halsband \& Hirche ([2001], compare their Figs. 2B \& $4 \mathrm{~A})$ recorded the highest fecundity and length of T. longicornis at the end of the spring phytoplankton bloom, when food sources were still sufficient (i.e. chl $\sim 5 \mu \mathrm{C} \mathrm{C}^{-1}$ ) to sustain $\mathrm{EPR}_{\max }$.

The relationship between EPR and chl, found in the present study, is not as strong and consistent as that between EPR and BW (Tables 3 to 5). One reason for this is perhaps that Temora longicornis can reproduce and reach $E P R_{\max }$ at food concentrations as low as $\sim 0.5 \mu \mathrm{g} \mathrm{C}^{-1}$ (Peterson \& Bellantoni 1987, Peterson et al. 1991, Bautista et al. 1994) and $\sim 1 \mu \mathrm{g} \mathrm{chl} \mathrm{l}^{-1}$ (present study), respectively. Another possibility is that our results are based on a relationship between EPR and in situ rather than ingested chl and that this approach does not take into account microzooplankton as a potential food source. Being an omnivore, T. longicornis is able to exploit a variety of food sources, including microzooplankton, which may represent up to $1 / 3$ of the daily nitrogen requirement of this species (Peterson \& Dam 1996). The largest proportion of chl during the spring phytoplankton bloom was due to Phaeocystis spp., a phytoplankton species, which is not usually grazed upon in large amounts by copepods (Hansen et al. 1993, Castellani et al. 2005). As ciliate biomass also peaked during the bloom, it is possible that $T$. longicornis preferentially selected microzooplankton over Phaeocystis spp., similar to what has been reported by Hansen et al. (1993). Thus, since T. longicornis may select its food according to type $\left(\mathrm{O}^{\prime}\right.$ Connors et al. 1980), size (Dam \& Peterson 1991) and quality, and feed carnivorously (Hansen et al. 1993), a weaker relationship between EPR and total available chl may be expected.

During spring 1996 Temora longicornis EPR was consistently lower than that in 1997 to 1998 over the full range of copepod weights for comparable chl concentrations, microplankton composition and SPM loading. The observed high variability in fecundity and poor correlation between EPR and chl may also have resulted from copepods ingesting food of different qualities. The quality of food depends on the biochemical components of the diet that cannot be synthesised by the copepods, in particular long-chain fatty acids (Pond et al. 1996), amino acids (Guisande et al. 2000), sterols (Klein Breteler et al. 1999), proteins (Kleppel \& Hazzard 2000) and vitamins (Lee et al. 1999). Variations in absolute egg numbers may also be due to the different age structures in the populations, i.e. the proportion of spent females (Uye 1981). However, our data show that the percentage of RAFs found during spring was similar across years. These considerations suggest that food quality, rather than copepod size and age, may have determined the inter-annual differences in the fecundity measured.

In the present study, the weight-specific fecundity (SEPR) of Temora longicornis was at most $10 \%$ body carbon $\mathrm{d}^{-1}$ (i.e. body $\mathrm{C} \mathrm{d}^{-1}$ ). Thus, the daily carbon rations of this species would be at most $30 \%$ body $\mathrm{C}$ $\mathrm{d}^{-1}$, assuming a gross growth efficiency (GGE) of $\sim 30 \%$ (Straile 1997). Dam \& Peterson (1993) constructed a carbon budget for $T$. longicornis, based on phytoplankton ingestion only, that would be consistent with this inference. However, since T. longicornis is an omnivore, carbon consumption is likely to be greater than the inferred ration, and the GGE is much less. Dam \& Lopes (2003) have recently estimated a GGE of $\sim 9 \%$ for $T$. longicornis fed 7 different diets, which would support this view.

\section{Effect of SPM on EPR}

Temora longicornis EPR was significantly inversely related to both SPM and tidal range (Fig. 7, Table 1). Butler (1995) has reported that all concentrations of suspended sediments significantly lowered the ability of the herbivorous freshwater copepod Diaptomus ashlandii to locate and ingest micro-algae. However, Gasparini \& Castel (1997) have suggested that the low fecundity of Acartia bifilosa in the Gironde estuary may be related to poor feeding conditions associated with high suspended particulate loading. Thus, T. longicornis fecundity may have been reduced either directly due to suspended sediments lowering feeding efficiency or indirectly through the ingestion of food of lower nutritional quality, i.e. degraded material derived from the bottom sediments re-suspended in the water column during high tide. Nevertheless, the mechanisms through which SPM affects the EPR of $T$. longicornis are unclear at present and require further investigation.

\section{Methodological and statistical considerations in the analysis of EPR data}

Heterogeneity of results between studies might also have arisen as a consequence of using different methodological (e.g. single versus multiple animal 
incubations, length of incubation) and analytical techniques (e.g. simple logarithmic transformation versus $\mathrm{ln}$ $[x+1]$ transformation). Several authors have already discussed the importance of standardising the methodology used to determine EPR by incubating individual females and including zero values to estimate copepod population fecundity (Runge \& Roff 2000, McKinnon \& Duggan 2001). Zero values can be artificially excluded from the statistical analysis by, for instance, taking into account only reproductive females and/or using simple ln transformation rather than $\ln (x+1)$ (Hopcroft \& Roff 1998, Bunker \& Hirst 2004). Excluding zero values will both overestimate the fecundity of the population and produce an artificially higher explanatory power of the variables (as the variability of the data set will become reduced). To avoid this shortcoming, in the present study, we chose to analyse individual estimates rather than mean fecundity to fully take into account the influence of the outliers, i.e. the zero values and very high values (McKinnon \& Duggan 2001). The results of our analysis show that this latter approach yielded the same regression coefficients estimated using mean values and allowed us to take into account more accurately the effect of body size and to determine more effectively the relationship between variables (Tables $1 \& 3$ ).

\section{CONCLUSIONS}

The present study has shown that body weight, food concentration and suspended particulate matter are all important variables affecting the fecundity of Temora longicornis. However, the relative impact of each of these factors on the total number of eggs a female copepod can produce may vary during the year. Food limitation of EPR (i.e. either low food abundance/quality or high SPM) may play a more important role during winter, when copepods are larger and require more energy to meet basic metabolic costs. On the other hand, BW may be a more important factor in setting the upper limit of reproductive output during the summer, as copepods at this time are smaller. In addition, the inverse correlation between BW and $T$ suggests that temperature plays a more subtle role by indirectly determining the maximum potential reproductive output of $T$. longicornis through its control on BW. It is concluded that by regulating at least in situ physical parameters, such as $T$ and SPM, climate change may act as an important determinant of secondary production.

Acknowledgements. The authors thank R. P. Harris, A. G. Hirst, E. Fileman, L. Y. Mora, A. Mustard, A. B. Yule, P. Molyneux and 3 anonymous referees for improving an earlier version of the paper with their comments. We also thank J. Runge for suggesting the inclusion of a comparison between regression analyses carried out using means and total individual fecundity values. Y. Griffiths is also acknowledged for proof reading the paper.

\section{LITERATURE CITED}

Bartram WC (1980) Experimental development of a model for the feeding of neritic copepods on phytoplankton. J Plankton Res 3:25-51

Bautista B, Harris RP, Rodriguez V, Guerrero F (1994) Temporal variability in copepod fecundity during two different spring bloom periods in coastal waters off Plymouth (SW England). J Plankton Res 16:1367-1377

Buchan S, Floodgate GD, Crisp DJ (1967) Studies on the seasonal variation of the suspended matter in the Menai Strait. I. The inorganic fraction. Limnol Oceanogr 12: 419-431

Bunker A, Hirst A (2004) Fecundity of marine planktonic copepods: global rates and patterns in relation to chlorophyll $a$, temperature and body weight. Mar Ecol Prog Ser 279:161-181

Burdloff D, Gasparini S, Sautour B, Etcheber H, Castel J (2000) Is the copepod egg production in a highly turbid estuary (the Gironde, France) a function of the biochemical composition of seston? Aquat Ecol 34:164-175

Butler NM (1995) Effects of sediment loading on food perception and ingestion by freshwater copepods. Mar Freshw Behav Physiol 26:287-294

Castellani C (2002) Population dynamics and secondary production of the small copepods in the Menai Strait. PhD thesis, University of Wales, Bangor

Castellani C, Lucas I (2003) Seasonal variation in egg morphology and hatching success in the calanoid copepods Temora longicornis, Acartia clausi and Centropages hamatus. J Plankton Res 25:527-537

Castellani C, Irigoien X, Harris R, Lampitt R (2005) Feeding and reproduction of Oithona similis in the North Atlantic. Mar Ecol Prog Ser 288:173-182

Dagg MJ (1978) Estimated in situ egg production for the copepod Centropages typicus (Krøyer) in the New York Bight. J Exp Mar Biol Ecol 34:183-196

Dam HG, Lopes RM (2003) Omnivory in the calanoid copepod Temora longicornis: feeding, egg production and egg hatching rates. J Exp Mar Biol Ecol 292:119-137

Dam HG, Peterson WT (1991) In situ feeding behaviour of the copepod Temora longicornis: effect of seasonal changes in chlorophyll size fractions and female size. Mar Ecol Prog Ser 71:113-123

Dam HG, Peterson WT (1993) Seasonal contrasts in the diel vertical distribution, feeding behaviour and grazing impact of the copepod Temora longicornis in Long Island Sound. J Mar Res 51:561-594

Fransz HG, Gonzalez SR, Cadee GC, Hansen FC (1992) Longterm change of Temora longicornis (Copepoda: Calanoida) abundance in a Dutch tidal inlet (Marsdiep) in relation to eutrophication. Neth J Sea Res 30:23-32

Gasparini S, Castel J (1997) Autotrophic and heterotrophic nanoplankton in the diet of the estuarine copepods Eurytemora affinis and Acartia bifilosa. J Plankton Res 19: $877-890$

Guisande C, Riverio I, Maneiro I (2000) Comparisons among the amino acid composition of females, eggs and food to determine the relative importance of the food quantity and food quality to copepod reproduction. Mar Ecol Prog Ser 202:135-142

Halsband C, Hirche HJ (2001) Reproductive cycles of domi- 
nant calanoid copepods in the North Sea. Mar Ecol Prog Ser 209:219-229

Halsband-Lenk C, Hirche HJ, Carlotti F (2002) Temperature impact on reproduction and developmant of congener copepod populations. J Exp Mar Biol Ecol 271:121-153

Hansen FC, Reckermann M, Klein Breteler WCM, Riegman B (1993) Phaeocystis blooming enhanced by copepod predation on protozoa: evidence from incubation experiments. Mar Ecol Prog Ser 102:51-57

Hirakawa K (1991) Vertical distribution and reproduction of planktonic copepods in Toyama Bay, southern Japan Sea, with special reference to Metridia pacifica. Bull Plankton Soc Jpn Spec Vol:373-382

Hopcroft RR, Roff JC (1998) Zooplankton growth rates: the influence of the female size and resources on egg production of tropical marine copepods. Mar Biol 132:79-86

Jónasdóttir SH (1994) Effect of food quality on the reproductive success of Acartia tonsa and Acartia hudsonica: laboratory observations. Mar Biol 121:67-81

Jónasdóttir SH, Gudfinnsson HG, Gislason A, Astthorsson OS (2002) Diet composition and quality for Calanus finmarchicus egg production and hatching success off southwest Iceland. Mar Biol 140:1195-1206

Kiørboe T, Nielsen TG (1994) Regulation of zooplankton biomass and production in a temperate coastal ecosystem: copepods. Limnol Oceanogr 39:493-507

Kiørboe T, Sabatini M (1995) Scaling of fecundity, growth and development in marine planktonic copepods. Mar Ecol Prog Ser 120:285-298

Kiørboe T, Mohlenberg F, Hamburger K (1985) Bioenergetics of the planktonic copepod Acartia tonsa: relation between feeding, egg production and respiration and composition of specific dynamic action. Mar Ecol Prog Ser 26:85-97

Klein Breteler WCM, Schogt N, Bass M (1999) Trophic upgrading of food quality by protozoans enhancing copepod growth: role of essential lipids. Mar Biol 135:191-198

Kleppel GS, Hazzard SE (2000) Diet and egg production of the copepod Acartia tonsa in Florida Bay. II. Role of the nutritional environment. Mar Biol 137:111-121

Kratzer S, Bowers D, Tett P (2000) Seasonal changes in colour ratios and optically active constituents in the optical Case2 waters of the Menai Strait, North Wales. Int J Remote Sens 21:2225-2246

Lee HW, Ban S, Ando Y, Ota T, Ikeda T (1999) Deleterious effect of diatom diets on egg production and hatching success in the marine copepod Pseudocalanus newmani. Plankton Biol Ecol 46:104-112

Maps F, Runge J, Zakardjian B, Joly P (2005) Egg production and hatching success of Temora longicornis (Copepoda, Calanoida) in the southern Gulf of St. Lawrence. Mar Ecol Prog Ser 285:117-128

McKinnon AD, Duggan S (2001) Summer egg production rates of paracalanid copepods in subtropical waters adjacent to Australia's North West Cape. Hydrobiologia 453/454:121-132

O'Connors HB Jr, Biggs DC, Nivaggi DV (1980) Particle size dependent maximum grazing rates for Temora longicornis fed natural particle assemblages. Mar Biol 56:65-70

Omori M, Ikeda T (1984) Methods in marine zooplankton ecology. Wiley, New York

Peterson WT, Bellantoni DC (1987) Relationship between

Editorial responsibility: Thomas Kiørboe (Contributing Editor), Charlottenlund, Denmark water column stratification, phytoplankton cell size and copepod fecundity in Long Island Sound and off central Chile. S Afr J Mar Sci 5:411-421

Peterson WT, Dam HG (1996) Pigment ingestion and egg production rates on the copepod Temora longicornis: implication for gut-pigment loss and omnivorous feeding. J Plankton Res 18:855-861

Peterson WT, Kimmerer WJ (1994) Processes controlling recruitment of the marine calanoid copepod Temora longicornis in Long Island Sound: egg production, egg mortality and cohort survival rates. Limnol Oceanogr 39: $1594-1605$

Peterson WT, Tiselius P, Kiørboe T (1991) Copepod egg production, moulting and growth rates, and secondary production in the Skaggerrak in August 1988. J Plankton Res 13:131-154

Pond D, Harris R, Head R, Harbour D (1996) Environmental and nutritional factors determining seasonal variability in the fecundity and egg viability of Calanus helgolandicus in coastal waters off Plymouth, UK. Mar Ecol Prog Ser 143: $45-63$

Putt M, Stoecker DK (1989) An experimentally determined carbon:volume ratio for marine 'oligotrichous' ciliates from estuarine and coastal waters. Limnol Oceanogr 34: 1097-1103

Runge JA (1985) Relationship of egg production of Calanus pacificus to seasonal changes in phytoplankton availability in Puget Sound, Washington. Limnol Oceanogr 30: 382-396

Runge JA, Roff JC (2000) The measurement of growth and reproductive rates. In: Harris RP, Wiebe $\mathrm{PH}$, Lenz J, Skioldal HR, Huntley M (eds) ICES zooplankton methodology manual. Academic Press, New York

Schmidt-Nielsen K (1991) Animal physiology, adaptation and environment, 4th edn. Cambridge University Press, Cambridge

Straile D (1997) Gross-growth efficiencies of protozoan and metazoan zooplankton and their dependence on food concentration, predator-prey weight ratio and taxonomic group. Limnol Oceanogr 42:1375-1385

Strathmann RR (1967) Estimating the organic carbon content of phytoplankton from cell volume or plasma volume. Limnol Oceanogr 12:411-418

Tett P (1987) 'Plankton'. In: Baker JM, Wolff WJ (eds) Biological surveys of estuaries and coasts. Cambridge University Press, Cambridge, p 328-335

Utermöhl H (1958) Zur Vervollkommnung der quantitativen Phytoplankton Methodik. Mitt Int Ver Theor Angew Limnol 9:1-38

Uye SI (1981) Fecundity studies of neritic calanoid copepods Acartia clausi Giesbrecht and A. steueri Simirnov: a simple empirical model of daily egg production. J Exp Mar Biol Ecol 50:255-271

White JR, Roman MR (1992) Egg production by the calanoid copepod Acartia tonsa in the mesohaline Chesapeake Bay: the importance of food resources and temperature. Mar Ecol Prog Ser 86:239-249

Williams R, Conway DVP, Hunt HG (1994) The role of copepods in the planktonic ecosystem of mixed and stratified waters of European shelf seas. Hydrobiologia 292/293: $521-530$

Submitted: March 24, 2004; Accepted: August 16, 2005 Proofs received from author(s): January 22, 2006 